\section{Shading of Tomato Plants Inconsistently Affects Fruit Yield}

\author{
V.M. Russo \\ U.S. Department of Agriculture, Agricultural Research Service, South Central \\ Agricultural Research Laboratory, P.O. Box 159, Lane, OK 74555
}

Additional index words. Lycopersicon esculentum, temperature stress, shade cloth, extending harvest

High day and/or night temperatures interfere with tomato fruit set (Berry and Uddin, 1988). Incorporating genetic resistance to detrimental effects of high temperature on tomato fruit set has not had uniform success. Thus, cultural methods are needed to supply tomato fruit for existing market windows. In the southern Plains, planting tomato by mid-April will produce marketable yields of $\approx 25 \mathrm{t} \cdot \mathrm{ha}^{-1}$ (Oklahoma State Univ., 1989, 1990). Day and night temperatures increase and yields tend to decrease as the season progresses. This experiment was designed to determine if shading could be used to increase yields and extend tomato fruit production season.

The experiment was conducted on a Bernow fine-loamy, siliceous, thermic Glossic Paleudalf soil at Lane, Okla. Fertilizer was applied at recommended rates when rough beds, lying east to west, were formed. Final beds, on $1.8-\mathrm{m}$ centers, were $20 \mathrm{~cm}$ high and $0.8 \mathrm{~m}$ wide. Plots were $6.1 \mathrm{~m}$ long with $2.4-\mathrm{m}$ alleys between them. Black plastic mulch $(0.032 \mathrm{~mm}$ thick) and drip irrigation $(23 \mathrm{~cm}$ between emitters) were applied after beds were formed. Six-week-old greenhouse-grown tomato (Lycopersicon esculentum Mill. cvs. Flash and Sunny) seedlings were transplanted $0.45 \mathrm{~m}$ apart on 15 May, 15 June, and 15 July in 1991 and 1992, with 12 plants per treatment. These cultivars are considered poor fruit setters under high temperatures.

In one-half of the plots, 1-m-wide, black, polypropylene $63 \%$ shade fabric was attached to cross members of T-shaped supports (1.6$\mathrm{cm}$-diameter reinforcing bar, $1.25 \mathrm{~m}$ above the bed surface) and to wire strung between cross member tips extending the length of the plots. The shadecloth, put in place 3 weeks after transplanting, was draped over the bed ends and secured to exclude direct solar radiation. Only reinforcing bar was placed in control beds. Plants were supported using the stake and weave method (Rhoads et al., 1988). Maximum-minimum temperature thermometers, suspended near centers of shaded and nonshaded plots $0.75 \mathrm{~m}$ above the bed surface, were monitored daily. Air temperatures and precipitation were recorded at a nearby weather station.

Received for publication 21 Dec. 1992. Accepted for publication 12 June 1993. The cost of publishing this paper was defrayed in part by the payment of page charges. Under postal regulations, this paper therefore must be hereby marked advertisement solely to indicate this fact.
The factorial experiments (two cultivars $x$ three planting dates $\times$ two shade treatments) were replicated four times in a randomized complete block. Fruit were harvested twice weekly. The last harvest was determined by the size of remaining fruit and the possibility that they would be harvestable. Total and marketable ( $\geq 58$ to $64 \mathrm{~mm}$ in diameter) fruit yields were recorded. In 1992, dry weight of the above-ground vegetative tissues from each planting date was recorded after the last harvest. Data were analyzed using general linear models in SAS (SAS, Inc., Cary, N.C.).

Average maximum and minimum air temperatures and total precipitation for cropping periods differed. In 1991, the average air minimum and maximum were 19.4 and $31.7 \mathrm{C}$, respectively. In 1992 , they were 16.8 and $28.7 \mathrm{C}$, ranging to $\approx 37 \mathrm{C}$ or above. Shade reduced the average air minimum and maximum by 1.0 and $2.5 \mathrm{C}$, respectively, in both years.

Planting month interacted with shade to affect total and marketable fruit yields (Table 1). Shade improved total fruit yield of plants established in June 1991, but failed to affect fruit yield for plants established in any month in 1992. Shading increased shoot dry weight and interacted with planting date and cultivar to influence shoot dry weights in 1992 (Table 1). Shoots of shaded 'Sunny' plants were heavier than those of nonshaded plants only when planted in May. Shade and planting yield, and shoot dry weight. respectively, by least squares means. month had no effect on shoot dry weights (average $89 \mathrm{~g}$ ) for 'Flash' plants. Plants established in May and June, but not July, had dry weights positively correlated $(P \leq 0.01)$ with total and marketable fruit yield (data not shown). The relationship between shoot dry weight and fruit yield may not have developed for plants established in July due to the shorter production period.

For glasshouse tomatoes planted in November, shading up to $23 \%$ reduced estimated total above-ground biomass (Cockshull et al., 1992). The temperatures recorded in Oklahoma were similar to those reported by Dane et al. (1991) as being detrimental to fruit set and pollen fertility of several tomato cultivars. Although shade-lowered air temperatures can favor fruit set, shading may have reduced net photosynthesis, or interfered with light-controlled plant morphogenesis, favoring vegetative development (Logendra et al., 1990).

Shading did not increase tomato fruit yield consistently, and its use is not justified.

\section{Literature Cited}

Berry, S.Z. and M.R. Uddin. 1988. Effect of high temperature on fruit set in tomato cultivars and selected germplasm. HortScience 23:606-608.

Cockshull, K.E., C.J. Graves, and C.R.J. Cave. 1992. The influence of shading on yield of glasshouse tomatoes. J. Hort. Sci. 67:11-24.

Dane, F., A.G. Hunter, and O.L. Chambliss. 1991. Fruit set, pollen fertility, and combining ability of selected tomato genotypes under high-temperature field conditions. J. Amer. Soc. Hort. Sci. 116:906910.

Logendra, S., J.D. Putnam, and H.W. Janes. 1990. The influence of light period on carbon partitioning, translocation and growth in tomato. Scientia Hort. 42:75-83.

Oklahoma State Univ. 1989.1988 Vegetable trial report. Hort 89-1. Oklahoma State Univ., Stillwater. Oklahoma State Univ. 1990.1989 Vegetable trial report. Hort 90-1. Oklahoma State Univ., Stillwater. Rhoads, F.M., S.M. Olson, and A. Manning. 1988. Nitrogen fertilization of staked tomatoes in north Florida. Soil \& Crop Sci. Soc. Fla. Proc. 47:42-44.

Table 1. Effect of planting month (P), cultivar (CV), and shading (S) on tomato total and marketable fruit

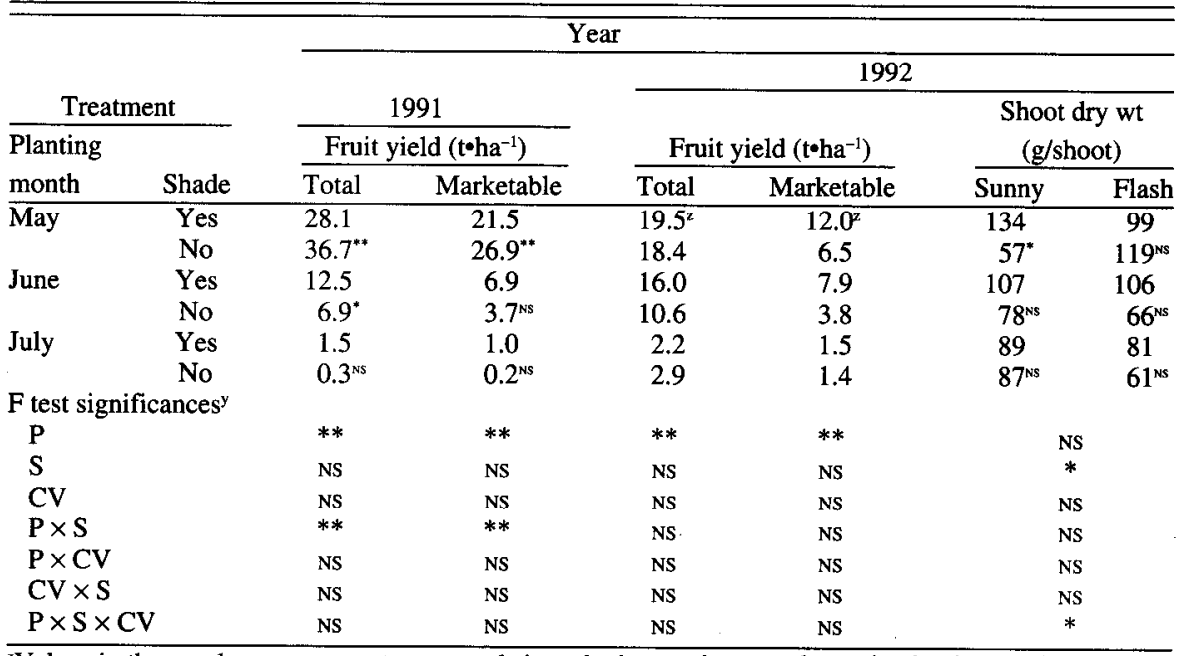

${ }^{2}$ Values in these columns were not compared since the interaction was determined to be nonsignificant. ${ }^{y}$ Nonsignificant (NS) or significant at $P \leq 0.05\left(^{*}\right)$ or $0.01(* *)$.

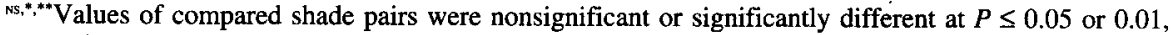

